\title{
The Building of Teaching Quality Evaluation System of Higher Vocational Education under the New Situation
}

\author{
Chunhong Li \\ Chongqing Business Vocational College
}

\begin{abstract}
With the increasingly close integration of industry and education in higher vocational colleges, the factors influencing the quality of talent cultivation in higher vocational education shows the characteristics of diversification and complexity. The deepening of teaching innovation and the continuous presentation of new teaching forms require the matching and coordination advance of teaching quality management. By analyzing the current situation and existing problems of teaching quality management in higher vocational education in China, this paper puts forward the principle of constructing the evaluation system of teaching quality in higher vocational education, constructs the evaluation system of "four parties participation and four kinds of evaluation" with modern information technology as the means, which is guided by the concept of scientific quality management, and puts forward some suggestions on the key point in the implementation process, which helps to establish a scientific, standardized and effective teaching quality evaluation system, and improve the vitality and compe titiveness of higher vocational colleges.
\end{abstract}

Keywords-Higher vocational teaching, Teaching quality; Evaluation system; Model

\section{The CurRent Situation And Problems of}

Teaching Quality Management in Higher Vocational EDUCATION IN CHINA.

\section{A. Current Situation}

The higher vocational and technical education in China has been developed for more than 30 years since its establishment in 1980, during which the higher vocational education in China has been developed rapidly and the number of higher vocational colleges has increased greatly. As of May 31, 2017, there were 2914 colleges and universities in China, including 1388 higher vocational and technical colleges, accounting for $47.63 \%$ of the national universities. Higher vocational education has become an important part of higher education in China. However, at the same time, in the process of rapid expansion of some colleges and universities, there are some problems in the teaching quality, such as insufficient teaching input, weak teachers strength, disjointed industry and education, especially the fast enrollment and employment of newly established higher vocational colleges. These schools lack a clear understanding of their own school goals, school system, talent training mode, teaching team construction, curriculum arrangement and so on, and the quality of teaching can't be guaranteed, which directly leads to the current situation of "graduation is unemployment", low employment rate and low social recognition.

According to the document No.6 of the "Opinions on Improving the Teaching Quality of Higher Vocational Education in an All-Round Way"[2015] of Ministry of Education, higher vocational colleges should focus on improving the quality. They should especially strengthen the construction of quality management system, and gradually improve the teaching quality assurance system with school as the core, with educational administration department guidance and social participation. At the same time, in order to implement the requirements of the "Decision on Accelerating the Development of Modern Vocational Education" of the State Council, the "Action Plan for Innovation and Development of Higher Vocational Education (2015-2018)" issued by the Ministry of Education in 2015 proposed that the modern vocational education teaching quality assurance mechanism that the internal guarantee of education is coordinated with the external evaluation of education should be established. Therefore, in order to improve the teaching quality of higher vocational education, we must establish a scientific, comprehensive and feasible teaching quality evaluation system, so as to ensure and continuously improve the teaching quality of higher vocational education.

\section{B. Existing Problems}

Under the economic new normal, vocational education also enters a new situation[5]. In recent years, with the increasingly close integration of industry and education in higher vocational colleges, the factors influencing the quality of talent cultivation in higher vocational education shows the characteristics of diversification and complexity. The deepening of teaching innovation and the continuous presentation of new teaching forms require the matching and coordination advance of teaching quality management[2].

Although the higher vocational colleges have attached great importance to the improvement of teaching quality and constantly improve the internal control system of teaching quality in recent years, there are still a lot of problems in the construction of the evaluation system for the quality of education and teaching in higher vocational colleges[4][6](See table below). The above problems will inevitably restrict the improvement of the teaching quality of higher vocational colleges in the new form, and affect the sustainable development of higher vocational colleges. Therefore, the 
higher vocational colleges must construct the teaching quality

evaluation system matching the new situation.

TABLE I. THE MAIN PROBLEMS EXISTING IN THE CONST RUCTION OF TEACHING QUALITY EVALUATION SYSTEM IN HIGHER VOCATIONAL EDUCATION

\begin{tabular}{|c|c|c|}
\hline Number & Main problems & Specific description \\
\hline \multirow{3}{*}{1} & \multirow{3}{*}{$\begin{array}{l}\text { The concept of } \\
\text { teaching quality } \\
\text { evaluation }\end{array}$} & Higher vocational colleges pay little attention to teaching evaluation, and the evaluation process only emphasizes form. \\
\hline & & $\begin{array}{l}\text { In the evaluation system, the evaluation of students, peers and supervisors is mostly used, and the subjectivity is } \\
\text { stronger }\end{array}$ \\
\hline & & $\begin{array}{l}\text { The power and responsibility of the personnel involved in the evaluation system are not clear, and the thought of } \\
\text { "official standard" is serious }\end{array}$ \\
\hline \multirow{2}{*}{2} & \multirow{2}{*}{$\begin{array}{l}\text { The subject of } \\
\text { teaching quality } \\
\text { evaluation }\end{array}$} & The school lacks specialized, sound and independent evaluation organizations. \\
\hline & & The three party evaluation systemsuch as enterprises and society is not perfect. \\
\hline \multirow{3}{*}{3} & \multirow{3}{*}{$\begin{array}{c}\text { Standard of teaching } \\
\text { quality evaluation }\end{array}$} & $\begin{array}{l}\text { The standard of teaching quality evaluation is single. The curriculum system adopted by different departments and } \\
\text { majors is quite different from the training mode of students, so the evaluation standard should be "tailored", however, at } \\
\text { present, most vocational colleges adopt a unified evaluation standard, which is unfair. }\end{array}$ \\
\hline & & The evaluation standard has not been highly quantified, and the standard systemis not comprehensive and objective. \\
\hline & & $\begin{array}{l}\text { The method of statisticalanalysis is backward, and the efficiency is low. At present, the informationization degree of } \\
\text { teaching quality evaluation system in higher vocational colleges is low, which can't guarantee information feedback } \\
\text { timely and efficiently, and affects the overall efficiency of evaluation systemmanagement. }\end{array}$ \\
\hline \multirow{3}{*}{4} & \multirow{3}{*}{$\begin{array}{c}\text { Feedback of teaching } \\
\text { quality evaluation }\end{array}$} & $\begin{array}{l}\text { There is a lack of authenticity in the "self-feedback" of the teaching affairs office, department and teaching and research } \\
\text { office. The teaching affairs office, department and teaching and research office are both referees and athletes, so the } \\
\text { teaching quality evaluation feedback is often positive feedback and less negative feedback. }\end{array}$ \\
\hline & & $\begin{array}{l}\text { Student feedback that is the final evaluation. Teachers only know the grades or scores, but they are not clear about the } \\
\text { specific content of the students' feedback, ignoring the problems and shortcomings of the teachers in teaching reflected } \\
\text { through the evaluation of the quality of teaching. }\end{array}$ \\
\hline & & The feedback from supervisor and peer evaluation is not true and comprehensive. \\
\hline
\end{tabular}

Data sources: According to the official website of our vocational colleges, we collect and sort out.

II. Construction Principle of Teaching Quality EVALUATION SYSTEM IN HighER VOCATIONAL EDUCATION

The purpose of implementing teaching quality evaluation in higher vocational colleges is to monitor the whole process of education and teaching, collect useful information, provide basis for educational decision-making, improve teaching quality constantly, and finally achieve the goal of talent training. Based on literature research, interviews in higher vocational colleges, expert consultation, etc., the evaluation system of teaching quality in higher vocational colleges should follow the following principles[3]:

\section{A. Operational Principle}

In order to achieve the goal of improving the teaching quality, the evaluation of teaching quality should have practical characteristics, so the design index should be able to collect information data easily. The index selection should be feasible and operable, and the index selection is relatively simple. The index should be less but more precise, which is beneficial to mastering and promoting.

\section{B. Principle of Accuracy}

The evaluation index is a "baton", representing the direction of development of higher vocational colleges. The evaluation of teaching quality should not only guide teachers to clear the direction of their own efforts, but also reflect the focus of the work of higher vocational colleges. At the same time, it is necessary to consider the combination of theory and practice. Therefore, the selection of evaluation indexes of teaching quality in higher vocational colleges should take full consideration of effective data support, and can be effectively supported by other ways to reflect the basic situation of teaching process and provide decision-making basis for the formulation of leadership policy.

\section{The Principle of Combination of Qualitative Evaluation and Quantitative Evaluation}

The quantitative index can be directly measured by numerical value, which improves the accuracy of teaching quality evaluation. In the analysis of quantitative index, the index system contains both absolute and relative indexes, therefore, we should choose a suitable method to make dimensionless treatment for the quantitative indexes before the comparison and analysis. The qualitative index reflects the teaching process objectively and it is simple and easy to use, however, it can't use data to reflect intuitively, and it has to use experience, logical thinking and other methods. The result of evaluation can easily lead to formalism. The above two methods will cause a certain degree of error in the evaluation process, so the paper selects the qualitative and quantitative evaluation method in the process of index selection, so that the evaluation results are more reasonable and fair.

\section{Principle of Feedback}

The evaluation of teaching quality in higher vocational colleges is to obtain useful information in the process of education and teaching in time, and provide basis for educational decision-making so as to adjust and control teaching activities in time and improve the quality of teaching. The feedback principle is that teachers find out their own shortcomings in teaching process through the evaluation results, and improve their teaching methods. On the other hand, managers of higher vocational colleges make targeted policies and systems through evaluation results, so as to improve 
teaching environment and ensure balanced operation of teaching.

\section{CONSTRUCtion OF TEACHING QuAlity EVAluAtion SYSTEM IN HighER VOCATIONAL EDUCATION}

Teaching quality is the core of the quality of personnel training. The evaluation of teaching quality in higher vocational colleges is an objective and impartial and comprehensive judgment of the quality of teaching in the term under the guidance of certain targets, using specific indicators and standards and scientific research methods, according to certain scoring standards and procedures[1]. The evaluation of teaching quality plays a decisive role in the development of higher vocational colleges. First of all, teaching quality is the core competitiveness of higher vocational colleges and universities, and it is also the key to ensure the quality of talent training. Secondly, the construction of teaching quality evaluation index system is conducive to the clear direction of the efforts of college teachers, thus indicating the direction of the long-term stable development of higher vocational colleges. Thirdly, the evaluation of teaching quality can provide sufficient basis for the job title appraisal, performance appraisal, and incentives of university teachers, which is conducive to promoting the construction of college teachers.

\section{A. Model of Evaluation System of Education and Teaching Quality in Higher Vocational Colleges}

We are guided by the concept of scientific quality management, using modern information technology as a means of constructing a teaching quality evaluation system of "fourparty participation, four types of evaluation" (see the figure below). According to this model, the evaluation subject has four parties involved. In order to avoid a single and limited evaluation subject, students, teachers, supervisors, and the social community participate in teaching quality evaluation. Students play a feedback role in the evaluation of teaching quality. The evaluation of students in the process of teaching provides timely feedback on the effectiveness of the classroom. The teacher is the main body of teaching and the controller of the teaching process. Teaching regulation is the necessary ability of higher vocational teachers in teaching activities. Teachers control their teaching activities through conscious activities such as supervision, evaluation and feedback of teaching activities [3]. Supervision has played an important role in the evaluation of teaching quality in higher vocational colleges. In the model of the teaching quality evaluation system constructed in this paper, the innovative supervision will be divided into two parts, one is the school full-time supervision group, and the second is the supervision of the industry enterprise experts. The evaluation of the participation of industry experts in teaching quality is a powerful guarantee for improving the teaching quality of higher vocational education and a fundamental guarantee for the implementation of schoolenterprise cooperation. The evaluation of the teaching quality of higher vocational education in society is carried out in three aspects, including employers, parents, and graduates. Through the evaluation of the career development of graduates, the society finds out the shortcomings of the students in the employment process of the graduate students, which makes the curriculum setting meet the social needs.

In addition, this model constructs four types of evaluation index systems, namely, teaching process control, real-time evaluation of classroom teaching, monitoring of the postpractice, feedback on the career development of graduates. Teaching process control link is the teaching quality goal and process evaluation, and it is also the core part of teaching quality evaluation. The evaluation of classroom teaching is the evaluation of the teaching quality effect. Feedback on the teaching quality and effect is provided through student evaluation and escort evaluation. The monitoring of the postpractice is the node of the evaluation of teaching quality. This link is the transfer station for students to enter the society from the school, and it is mainly used to measure the satisfaction of students' post practice and the thesis defense status. The feedback on the career development of graduates is the result of the evaluation of teaching quality. The measurement of this process in turn acts on the teaching and operation of higher vocational education, including the formulation of personnel training programs and the number of teaching and research activities. The four processes of the evaluation of teaching quality in higher vocational education interact with each other to form a closed loop system. Problems in any one link may affect the overall teaching quality.

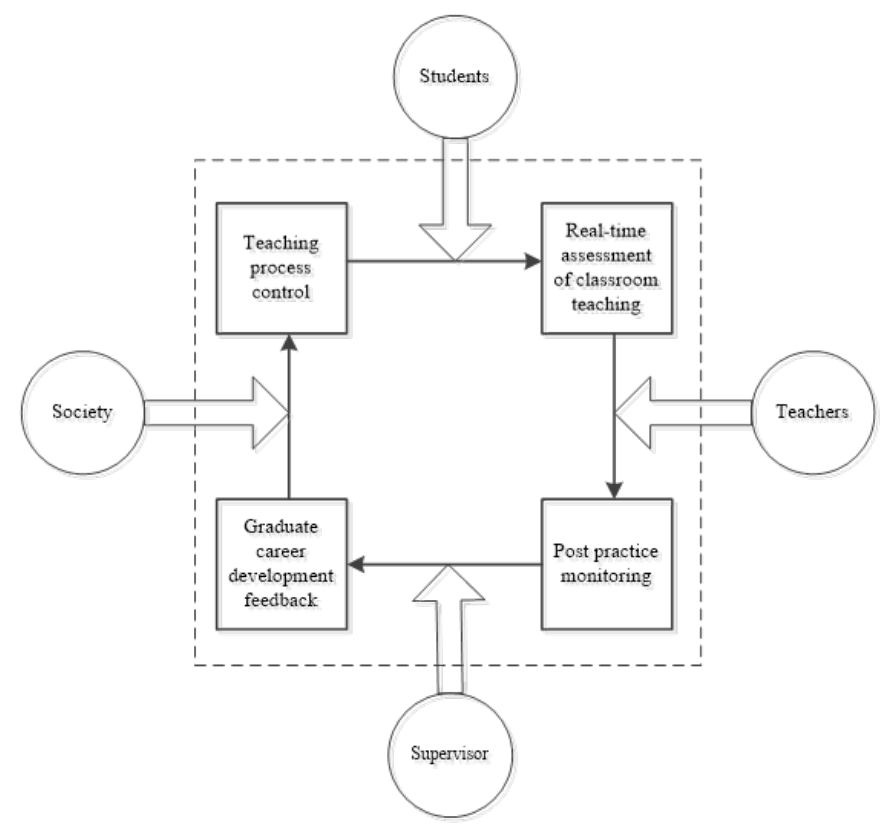

Fig. 1. Model of education and teaching quality evaluation system in higher vocational colleges

\section{B. Connotation Features of Evaluation System of Education and Teaching Quality in Higher Vocational Colleges}

The "four-party participation, four types of evaluation" teaching quality evaluation system has the following connotation features. The first one is transboundary. Cross schools and enterprises. Many parties participate. Not only school students, teachers, and supervisors participate in the evaluation of teaching, but employing units, parents, and graduates also participate in the evaluation of teaching, 
reflecting the cross-border evaluation. The second is extension. Extend the elements, and extend the space and time. The evaluation elements are expanded to four aspects, not only the control of the teaching process, but also the monitoring of classroom teaching and the post-practice, and the feedback of graduates' career development is also taken as an aspect of teaching quality evaluation. Evaluation time extends from now to future professional development. The third is interaction: comanagement and real-time interaction. Through the comanagement and promotion of four aspects of teachers, students, supervisors and society, the evaluation system can interact in real time, realize the interaction of information, and evaluate the quality of teaching in a comprehensive and scientific way. The fourth is timeliness. Based on data, it is real-time and efficient. Teaching evaluation uses modern information technology as a means to collect and process data, and it is timely and efficient.

\section{Index System of Evaluation of Education and Teaching Quality in Higher Vocational Colleges}

Based on the above models, through the literature review, the current situation of teaching quality evaluation in universities, and the summary, the index system suitable for teaching quality evaluation in higher vocational colleges is established as follows:

TABLE II. EVALUATION INDEX SYSTEM OF QUALITY IN HIGHER VOCATIONAL EDUCATION AND TEACHING

\begin{tabular}{|c|c|c|c|}
\hline Fist-level index & Second-level index & Third-level index & Evaluation methods \\
\hline \multirow{4}{*}{$\begin{array}{l}\text { Control of teaching } \\
\text { process }\end{array}$} & Talent training program & $\begin{array}{l}\text { Personnel training objectives, positioning scientificity and } \\
\text { execution ratio }\end{array}$ & $\begin{array}{c}\text { Teaching Guidance Committee, } \\
\text { industry and business supervision } \\
\text { expert, and Academic Affairs } \\
\text { Office review. }\end{array}$ \\
\hline & Professional construction & $\begin{array}{l}\text { The completion degree of professional construction plan, the } \\
\text { integration result of industry and teaching(the number of } \\
\text { enterprises cooperating with school, the modern academic } \\
\text { system, the result of order class), and the effect of } \\
\text { construction. }\end{array}$ & $\begin{array}{l}\text { Teaching Guidance Committee, } \\
\text { industry and business supervision } \\
\text { expert, and Academic Affairs } \\
\text { Office review. }\end{array}$ \\
\hline & Teacher practice & $\begin{array}{c}\text { The ratio of double type teachers, the rate of teachers' post } \\
\text { practice in enterprise and the rate of obtaining professional } \\
\text { qualification certificate of teachers }\end{array}$ & $\begin{array}{c}\text { Industry and business supervision } \\
\text { expert, and Academic Affairs } \\
\text { Office review. }\end{array}$ \\
\hline & Teaching activities & $\begin{array}{l}\text { The completion degree of teaching and research activities, } \\
\text { the completion degree of thematic teaching and research } \\
\text { activities, the number of curriculum development, the } \\
\text { number of awards for teachers' skills competition, and the } \\
\text { number of awards for professional competition instructors. }\end{array}$ & $\begin{array}{l}\text { Academic Affairs Office and } \\
\text { supervision department review. }\end{array}$ \\
\hline \multirow{4}{*}{$\begin{array}{l}\text { Real time } \\
\text { evaluation of } \\
\text { classroom teaching }\end{array}$} & In-class evaluation & $\begin{array}{l}\text { The teaching evaluation scores by supervisors through } \\
\text { listening to the class randomly, in-class evaluation scores of } \\
\text { teachers and in-class evaluation scores of students }\end{array}$ & $\begin{array}{l}\text { Academic Affairs Office and } \\
\text { supervision department review }\end{array}$ \\
\hline & Students' evaluation of teaching & The ranking of students' evaluation of teaching scores & $\begin{array}{l}\text { Academic Affairs Office and } \\
\text { supervision department review }\end{array}$ \\
\hline & Practice teaching examination & $\begin{array}{l}\text { Practice teaching curriculum standard, practice teaching } \\
\text { achievement, student satisfaction evaluation of practice } \\
\text { teaching }\end{array}$ & $\begin{array}{l}\text { Industry and business supervision } \\
\text { expert, Academic Affairs Office } \\
\text { and supervision department review }\end{array}$ \\
\hline & Network curriculum monitoring & $\begin{array}{c}\text { Online course completion degree and online course } \\
\text { satisfaction evaluation }\end{array}$ & $\begin{array}{c}\text { Academic Affairs Office and } \\
\text { supervision department review }\end{array}$ \\
\hline \multirow{6}{*}{$\begin{array}{l}\text { Monitoring of post } \\
\text { internship }\end{array}$} & Quality of graduation (paper) & $\begin{array}{l}\text { Repetition rate, ability to express words and number of } \\
\text { excellent graduation thes is }\end{array}$ & $\begin{array}{c}\text { Academic Affairs Office and } \\
\text { supervision department review }\end{array}$ \\
\hline & Post internship interview & $\begin{array}{l}\text { Performance excellence rate of students in the internship; } \\
\text { student satisfaction with internship. }\end{array}$ & $\begin{array}{l}\text { Industry and business supervision } \\
\text { expert, Academic Affairs Office } \\
\text { and supervision department review }\end{array}$ \\
\hline & $\begin{array}{l}\text { Joint defense between school and } \\
\text { enterprise }\end{array}$ & The good rate of graduation thesis defense & $\begin{array}{c}\text { Industry and business supervision } \\
\text { expert review }\end{array}$ \\
\hline & $\begin{array}{l}\text { Policy support for graduation } \\
\text { practice } \\
\end{array}$ & Student employment allowance. & $\begin{array}{l}\text { Academic Affairs Office and } \\
\text { Employment Department review }\end{array}$ \\
\hline & Practice training base & School enterprise cooperation unit number & $\begin{array}{l}\text { Academic Affairs Office and } \\
\text { supervision department review }\end{array}$ \\
\hline & $\begin{array}{l}\text { Professional teaching staff of } \\
\text { employment guidance }\end{array}$ & $\begin{array}{l}\text { The proportion of the number of professional employment } \\
\text { guidance teachers }\end{array}$ & $\begin{array}{l}\text { Industry and business supervision } \\
\text { expert, Academic Affairs Office } \\
\text { and supervision department review }\end{array}$ \\
\hline \multirow{6}{*}{$\begin{array}{l}\text { Feedback of } \\
\text { graduates' career } \\
\text { development }\end{array}$} & Graduate satisfaction & Graduate satisfaction & Review of professional institutions \\
\hline & Employer satisfaction & Employer satisfaction & Review of professional institutions \\
\hline & Third party evaluation & $\begin{array}{l}\text { Industry satisfaction and parents' satisfaction with student } \\
\text { employment. }\end{array}$ & Review of professional institutions \\
\hline & $\begin{array}{l}\text { Professional setup and enterprise } \\
\text { demand goodness of fit }\end{array}$ & Employment suited rate of graduates & Review of professional institutions \\
\hline & Graduates’ employment stability & The turnover rate of graduates for one to three years & Review of professional institutions \\
\hline & $\begin{array}{l}\text { The development track of graduates } \\
\text { after graduation }\end{array}$ & $\begin{array}{l}\text { The career promotion rate and the rate of students upgrading } \\
\text { from junior college to university }\end{array}$ & Review of professional institutions \\
\hline
\end{tabular}


The teaching quality evaluation index system includes four first-level indicators, 20 second-level indicators and 40 thirdlevel indicators. During the implementation of the evaluation, we invited senior management personnel of the school, middle and senior management personnel of enterprises, industry association experts, government personnel, and other university experts to use yaahp software to attach weight to each indicator. The pairwise comparison are made on the importance of each index at the same index level to the teaching quality of the upper level of the index (assignment based on the importance from 1-5) and a judgment matrix for comparing the two is constructed. Through the judgment matrix, the relative weights of the compared indicators for the total innovation evaluation are calculated, and consistency check of the matrix is performed. If the obtained consistency test result is greater than or equal to 0.1 , it indicates that the matrix construction is unreasonable, and the weights must be adjusted until the entire matrix consistency test results are less than 0.1 . We use surveys and data collection methods to obtain real-life data on teaching quality assessment. We use 0-1 standardized methods to process the acquired data, and then use the weighted average to obtain the final results of the evaluation of teaching quality. Through the analysis of the final results, we find out the weak links of teaching quality and propose targeted improvement measures to provide reasonable suggestions for the next step in the improvement of teaching quality and improvement of teaching procedures.

\section{SugGestions ON IMPLEMENTATION OF TEACHING Quality Evaluation System IN HigheR Vocational EDUCATION}

The first is to grasp the source system design quality. That is, through the design of the teaching process control index system, evaluation and monitoring are carried out on personnel training program design, teaching and research reform, professional construction, and teacher practice, and the quality of teaching is monitored from the source of personnel training.

The second is the monitoring of key elements of the process. That is, in the design of teaching evaluation index system, we must pay attention to the monitoring of key elements, such as personnel training programs, teaching reform and research activities, diverse teaching activities, real-time evaluation of classroom teaching, etc. [1].

The third is the integration of curriculum and practice[4]. That is, in the process of teaching quality evaluation, it is necessary to focus on the two aspects of curriculum teaching and practical teaching, and to implement the real-time evaluation of classroom teaching and the supervision of the post-practice.

The fourth is to evaluate the final student's achievement growth. That is, a follow-up survey of graduates and stakeholders is conducted, and the final students' achievement growth is taken as an important indicator of teaching quality evaluation.

\section{CONCLUSION}

The "four-party participation, four types of evaluation" teaching quality evaluation system constructs a teaching quality evaluation indicator framework from four aspects: teaching process control, real-time evaluation of classroom teaching, supervision of the internship practice, and tracking of graduates and stakeholders. These four aspects are the first-level indicators for the evaluation of teaching quality in higher vocational colleges. Each first-level indicator is subdivided into 4-6 sub-indexes to form a quality evaluation system from the goal, process to results. The characteristics of transboundary extension, interaction, and timeliness can provide an all-round evaluation of the quality of a school's education and teaching to ensure the quality of personnel training.

\section{REFERENCES}

[1] Xiaojuan Yin. Construction and Implementation of Multiplex Teaching Quality Monitoring System in Higher Vocational College[J]Higher Vocational Education-Journal of Tianjin Vocational Institute, 2012(4). (In Chinese)

[2] Xuemei Zhao. The Construction of Teaching Quality Monitoring and Evaluation System in Higher Vocational Colleges under the New Normal [J] Journal of Heze University, 2016 (10). (In Chinese)

[3] Gan Li. Construction of Teaching Quality Evaluation System in Higher Vocational Colleges [J], Education Teaching Forum, 2016 (23). (In Chinese)

[4] Xingying Qian. Higher Vocational Education Teaching Quality Assessment and Monitoring System [J], Vocational Education, 2015(146). (In Chinese)

[5] Yubao Du. Grasp the Development of Higher Education under the New Normal Condition [N], Guangming Daily, 2015-03-02. (In Chinese)

[6] Yue Wang. Higher Vocational Education Quality Problems about the Literature Review [J], Communication of Vocational Education, 2012 (13): 72-74. (In Chinese) 